\title{
James R. Millar, 1936-2008
}

Slavic studies has lost one of its pioneers. James R. Millar spent the first half of his illustrious career at the University of Illinois and the second half at George Washington University, where he headed the Elliot School's Institute for European, Russian, and Eurasian Studies. He received his PhD from Cornell University, but he conducted his research at Harvard University's Russian Research Center at the height of its intellectual activity. Jim remembered this time with fondness. His work was heavily influenced by Abram Bergson, who had gathered in the Russian Research Center a distinguished group of economists doing landmark research on the Soviet economy. I believe that Jim's goal in his scholarly life was to carry forward this tradition in his own work.

Jim broke on the academic scene with his pathbreaking analysis of Soviet agriculture's failure to produce a "net surplus." This work prompted a major rethinking of the conventional wisdom about collectivization. The issues Jim raised in his agricultural surplus papers of the early 1970s prompted a debate among major scholars that continues to the present day. Jim was the first scholar to measure the economic costs of World War II to the USSR, and his ABCs of Soviet Socialism (1981) laid out a conceptual framework for studying the Soviet economy.

In the 1980s, Jim served as director of the Soviet Interview Project (SIP), which surveyed recent emigrants, primarily of Jewish origin, on their daily life and work in the Soviet Union. SIP produced a series of books, including the capstone volume Politics, Work, and Daily Life in the USSR (1987), which presented a comprehensive view of the Soviet Union as of the mid to late 1970s. Under Jim's leadership, the SIP team applied the tools of modern social sciences, such as quantitative methods and survey research, that now dominate transition studies. Under Jim's leadership, SIP also provided a training ground for then-junior scholars, who went on to become some of the leading scholars in our field. SIP today provides a benchmark, along with a smaller project carried out in Israel by Gur Ofer, for those doing survey research on contemporary Russia. Of the many findings of the SIP project, the most important was that Soviet citizens were reasonably satisfied with their lives; thus the end of the Soviet system was not caused by bottom-up forces. It was the system's leaders who chose, perhaps unwittingly, to end the Soviet system.

In 1991, Jim was chosen by Congress to head a panel of scholars assembled to assess the intelligence community's failure to predict the Soviet collapse. His ability to work effectively with teams of scholars is also reflected in his editorship of the massive Encyclopedia of Russian History (2004). Beginning in 2000, Jim served as scholar in residence at the Central Intelligence Agency. His scholarship turned to the issue of "empire envy," a prescient move in light of recent events in Georgia and Ukraine. In recent years, Jim returned to his work as the unofficial historian of the field of Soviet economics, digging deeply into the Abram Bergson archives at Harvard for a work that he unfortunately was unable to finish. For those who knew Jim well, he will be remembered for his scholarship, mentoring, diplomacy, equanimity, service, and good sense.

Finally, I should note that Jim was a rare specimen of a truly interdisciplinary scholar. Editor of both Slavic Review and Problems of Post-Communism, Jim also served as president, vice president, and lastly treasurer of the American Association for the Advancement of Slavic Studies (AAASS). In addition, he served on the boards of the International Research and Exchanges Board, the National Council for Eurasian and East European Research, and the American Council of Learned Societies. For these services and his scholarship, Jim was justly awarded AAASS's highest honor in 2006, the award for Distinguished Contributions to Slavic Studies.

The members of Jim's SIP team will remember our meetings in a nondescript office building next to the New York post office or on the campus of the University of Chicago and our stays in rundown Manhattan or Hyde Park hotels. Although the work itself was occasionally tedious, these meetings were filled with the excitement of trying to do something new. None of us had ever written a questionnaire, organized a large stratified

Slavic Review 68, no. 2 (Summer 2009) 
sample, or conducted in-depth interviews. SIP also had to find a large cadre of young Russian speakers, most drawn from universities, to actually administer the questionnaire. It would be interesting to count how many went on to scholarly careers. At SIP we were also fortunate to have the sage advice of Joseph Berliner. In a number of conversations, Jim praised the decorum that was a part of the Brandeis department of economics, of which Joe was a member. As he saw it, with a gentleman like Berliner around, no one would think of engaging in noncollegial behavior. I feel that Jim played much the same role in his own life.

Paul Gregory

University of Houston

January 2009 